\title{
地款近傍に打りる熱過程
}

\author{
一一松沢の“場の論”に含まれる熱過程をめぐつて—— \\ 東京大学理学部地球物理学教室 安 芸 敬 一 \\ (昭和 28 年 12 月 20 日受理)
}

\section{Thermal Processes near the Earth's Crust}

\author{
Keiiti Акा
}

Geophysical Institute, Faculty of Science, Tokyo University.

(Received December 20, 1953)

The possible thermal processes near the earth's crust are studied with special regard to a process presented by Prof. Matuzawa in his recent paper titled "Feldtheorie der Erdbeben.", in which a solid-liquid transformation plays an important part. Before the discussion of this particular process, the present writer gives the necessary condition for the stationary conversion of thermal energy into mechanical energy inside a system of material through which a stationary heat flow exists. It is shown that this condition is satisfied near the crust in two and only two cases, of which in the first a mass flow exists in the system, and in the second the relation $\alpha=\beta+1$ exists between the number $\alpha$ of phases and the number $\beta$ of components of the system. The first case corresponds to the convection theories of the cause of earthquake and the second corresponds to the phase transformation theories, to which Prof. Matsuzawa's theory belongs. The necessary heat supply for a great earthquake was shown quantitatively in his paper. It is emphasized that such an amount of heat energy can only be supplied by the convection current under the crust. And the writer obtains by the aid of experimental and theoretical laws of heat transfer through a free convection the relation between the scale of convection and the viscosity of material under the crust required for the effective operation of Matuzawa's process. If such a convection has a scale of $100 \mathrm{~km}$, the viscosity of material must be $10^{17}$ poise, its maximum current velocity is estimated to be $50 \mathrm{~m} /$ year and it exerts a tangential stress of the order of $10^{7} \mathrm{dyne} / \mathrm{cm}^{2}$ along the lower surface of the crust.

Those results that the subcrustal current which is believed to account for the mountain formation may accompany Matuzawa's process, that Matuzawa's process which amply explains the cause of a great earthquake needs the heat energy supplied by the subcrustal current which also exerts a considerable stress, and that the possible stationary conversion of the thermal energy into mechanical energy must by confined to the above two cases, may lead us to the conclusion that those two processes combined play a very important part in the physical phenomena near the earth's crust.

\section{$\S 1$ 緒 論}

地震少，地殼内部に貯えられた歪エネルギーの放出であるという考えは，多くの人々によつ 
て支持されている. 坪井 ${ }^{1)}$ は, 地震とは結局, 不安定の場のエネルギーの問題であると述べて いる. そして, 此の不安定の場は, 例えば, Grigg, Meinesz 等によれば地殼下の対流によつ て，Joly，Daly 等によれば相変化に伴う内部圧力の変化によって生ずる．最近松沢2) は，相 変化によって地震が発生する過程を定量的に議論した。それによれば，500 立方粁の地下物質 が融解によって，その体積を一割増加し，300 気圧の圧力増加が生じて，地殼を隆起させ，同 時に歪エネルギーを貯える. 地殼が隆起に伴って重力場でなす仕事は $4 \times 10^{26} \mathrm{erg}$. であり，

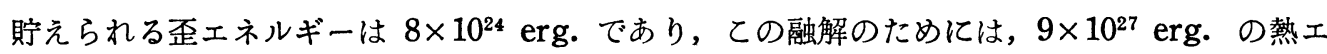
ネルギーを必要とする，そしてての熱は，下からばかりでなく，横からも，熱伝導，熱対流を 通じて供給される．松沢の考えた過程を簡単にのべれば以上の如くであるが，熱の供給の問題 は, なお不明瞭であつて, 定量的な検討が必要に思われる. ての熱エネルギーの供給の種々の 可能性をしらべる前に, われわれが，地殼の近傍で，考えるてとのできるあらゆる熱的過程の 内から，ある条件を満たす過程だけをえらびだすてとは意義があると思う。

熱エネルギーから, 仕事えの転化は, 普通体積変化を通じて行われると考えてよい. 例えば 重力場での熱対流も, 密度変化に伴う仕事で維持される. そしてある物質部分の体積変化は, その部分えの熱の貯溜によっで行われる. その部分を通じていくら熱が流れても，貯溜が零で あつては，仕事に变らない，地殼近傍での熱の貯溜を考えるに際して，ての論文ではその原因 を何かわからない突発現象に帰せしめることを避け，地殼の深部に高熱源を仮定し，そてから 地表え定常的に熱が流れ乍ら，途中で貯溜される場合だけが重要であると考えた．但し，定常 というととの中に，回帰的な場合をも含める.

\section{§ 2. 定常的な熱の貯留のための条件}

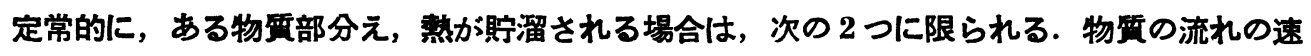
度を $V$ として,

1. $V \neq 0$

\section{$V=0$ の場合には, その系の成分の数を $\beta$, 相の数を $\alpha$ として,}

2. $\alpha=\beta+1$

1. の証明は簡単である. 外部から物質部分えの熱の供給量は, 単位時間当り, $k$ を熱伝導 率として,

$$
k \int \nabla^{2} T d v
$$

である. 熱の伝達の式は, $c$ を比熱, $\rho$ を密度として,

$$
\frac{\partial T}{\partial t}+(V \cdot \operatorname{grad}) T=a \nabla^{2} T, \quad a=\frac{k}{\rho c}
$$


であるから，定常即わち $\frac{\partial T}{\partial t}=0$ の場合にも，Vキ0ならば, $\nabla^{2} T \neq 0$ であつて，熱は貯溜さ れる. これは，定常的な熱対流をあらわす。

2. $V=0, \frac{\partial T}{\partial t}=0$, であれば, 熱の貯溜は不可能に見えるが，熱伝達の式は正確には，

$$
T-\frac{\partial S}{\partial t}=\frac{k}{\rho} \nabla^{2} T
$$

とかかれるべきであって，

$$
\frac{\partial S}{\partial t}=\left(\frac{\partial S}{\partial T}\right)_{P . \boldsymbol{\mu .}} \frac{\partial T}{\partial t}+\left(\frac{\partial S}{\partial P}\right)_{T . \boldsymbol{k} .} \frac{\partial P}{\partial t}+\Sigma \Sigma\left(\frac{\partial S}{\partial M_{n}^{i}}\right)_{P . T .} \frac{\partial M_{n}^{i}}{\partial t}
$$

であるから， $\frac{\partial T}{\partial t}=0$ でも, $T-\frac{\partial S}{\partial t}=\frac{k}{\rho} \nabla^{2} T \neq 0$ となる場合がある. こてに $S$ は, 単位質量当 りのエントロピー, $P$ は圧力, $M_{n}^{i}$ は $i$ 番目の相の $n$ 番目の成分のモル数を表わす. ある相 の組成は, 濃度 $c_{n}^{i}$ できまる。

$$
\begin{aligned}
& c_{n}^{i}=M_{n}^{i} / \sum_{n} M_{n}^{i}=M_{n}^{i} / M^{i} \\
& \frac{\partial M_{n}^{i}}{\partial t}=M^{i} \frac{\partial c_{n}^{i}}{\partial t}+c_{n}^{i} \frac{\partial M^{i}}{\partial t}
\end{aligned}
$$

系が閉されているとして，

$$
\begin{aligned}
& \frac{\partial}{\partial t}\left(\sum_{i} M_{n}^{i}\right)=0 \quad(n=1,2, \ldots \ldots, \beta) \\
& \sum_{i}\left(M^{i} \frac{\partial c_{n}^{i}}{\partial t}+c_{n}^{i} \frac{\partial M^{i}}{\partial t}\right)=0 \quad(n=1,2, \ldots \ldots, \beta)
\end{aligned}
$$

の $\beta$ ケの条件がある.

相律によって， $\alpha>\beta+2$ の場合は有り得ないから， $\alpha=\beta+2$ の場合から考える, この場合 には, 圧力, 温度, 組成, 共に一通りの值しかとり得ない。そのような条件が，地球内部で， 成立しているとは考えられない。

$\alpha=\beta+1$ の場合には，圧力が決まれば，温度も組成も決まるから， $\frac{\partial P}{\partial t}=0$ ならば $\frac{\partial T}{\partial t}=\frac{\partial c_{n}^{i}}{\partial t}=0$ である. それ故,

$$
\begin{aligned}
\partial S= & \left(\frac{\partial S}{\partial T}\right)_{P . M .} \frac{\partial T}{\partial t}+\left(\frac{\partial S}{\partial P}\right)_{T . M .} \frac{\partial P}{\partial t}+\sum \sum\left(\frac{\partial S}{\partial M_{n}^{i}}\right)_{P_{*} \cdot T .} M^{i} \frac{\partial c_{n}^{i}}{\partial t} \\
& +\Sigma\left\{\sum\left(\frac{\partial S}{\partial M_{n}^{i}}\right)_{P . T .} \cdot c_{n}^{i}\right\} \frac{\partial M^{i}}{\partial t}=\sum_{i=1}^{\alpha}\left\{\sum_{n=1}^{\beta}\left(\frac{\partial S}{\partial M_{n}^{i}}\right)_{P . T .} \cdot c_{n}^{i}\right\} \frac{\partial M^{i}}{\partial t}
\end{aligned}
$$

一方，(8) の条件によって， $\frac{\partial M^{i}}{\partial t}$ の内自由なのは, $\alpha-\beta(=1)$ 箇である. したがって, 
$\alpha=\beta+1$ の場合には，熱は(9)式に従つて定常的に貯溜される. 又, $\frac{\partial P}{\partial t}=0$ でなくとも, 圧 力が $\oint d P=0$ に従つて回帰的に変化する場合には, 温度も回帰的に変化し, (即ち $\oint d T=0$, ） その間に，熱は，

$$
\oint d S=\phi \sum_{i=1}^{\alpha}\left\{\sum_{n=1}^{\beta}\left(\frac{\partial S}{\partial M_{n}^{i}} \cdot c_{n}^{i}\right)\right\} d M^{i} \neq 0
$$

に従って貯溜される.

$\alpha \leq \beta$ の場合には，圧力及び， $\beta-\alpha+1$ 箇の $c_{n}^{i}$ を一定にするととが可能なら, $\frac{\partial T}{\partial t}=0$, $\frac{\partial c_{n}^{i}}{\partial t}=0$ となるが， $M^{i}$ の内独立なものは，( $\alpha-\beta \leq 0$ であって）あり得ないから

$$
\frac{\partial S}{\partial t}=\sum_{i=1}^{\alpha}\left\{\sum_{n=1}^{\beta}\left(\frac{\partial S}{\partial M_{n}^{i}} \cdot c_{n}^{i}\right)\right\} \frac{\partial M^{i}}{\partial t}=0
$$

となる.したがって定常的な熱の貯溜は行われない.

例えば，一成分の場合には，二相共存にある系にのみ，定常的な熱の貯溜が行われる. 具体 的に云うと, 地殼を通して流れる熱量は, その厚さと, 熱伝導率と, その底面温度と地表温度 で定まるが，その底面の温度がそこの物質の融点であれば，その場所の圧力によつて定つた值 をとるから，流れる熱も定つた値をとる．それ故下からその值以上の熱が流れとめば，その場 所に溜らないわけには行かず，乙の熱は，体積変化を通して仕事をする他ない。乙れが，松沢 の過程を生ぜしめるととになる。

§3. 松沢過程を維持するための熱エネルギー. 地表で観測される熱の流れは，平均，

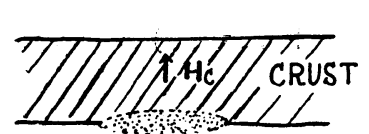

$\uparrow H_{M}$

$H_{\sigma}=1.3 \times 10^{-6} \mathrm{cal} . \mathrm{cm}^{-2} \mathrm{sec}^{-1}$ である. 一方, 100 年に 1 度, 半径 $50 \mathrm{~km}$ の範囲に, $O\left(10^{25}\right) \mathrm{erg}$ の地震が起るとして, それが松沢過 程によるとすれば， $O\left(10^{27}\right) \mathrm{erg}$ の熱エネルギーが，作業物質中

Fig. 1 Heat flow through 貯溜されねばならない。これは熱の流れに換算すると， the working material.

$H_{M}=O\left(10^{-4}\right) \mathrm{cal} \mathrm{cm}^{-2} \mathrm{sec}^{-1}$ である：それ故, 熱源から供給される ベき熱流は， $H_{\sigma}+H_{M}=O\left(10^{-4}\right) \mathrm{cal} \mathrm{cm}^{-2} \mathrm{sec}^{-1}$ であり，地殼を流れている熱流の 100 倍である。 これだけの熱を供給するのに，どのような可能性があるだろうか.

a. 放射性エネルギー．地表で観測した火成岩中の放射性熱エネルギーを次に示す。 (3)

Table 1. Radioactive heat generation of igneous rocks. (after R. D. Evans and C. Goodman)

\begin{tabular}{|l|l|}
\hline \multicolumn{1}{|c|}{ Rock Type } & Heat Generation \\
\hline Acidic Igneous Rock & $1.7 \times 10^{-13} \mathrm{cal} \mathrm{gr.}^{-1} \mathrm{sec}^{-1}$ \\
\hline Basic Igneous Rock & $0.6 \times 10^{-13}$ \\
\hline Ultra basic Igneous Rock & $0.3 \times 10^{-18}$ \\
\hline
\end{tabular}


松沢過程の作業物質が，内部に放射性物質を含む場合，単位質量当りの熱エネルギーの生産が， 地表で観測される值と余り異ならないとすれば,それによる熱の流れは作業物質の厚さを $1 \mathrm{~km}$

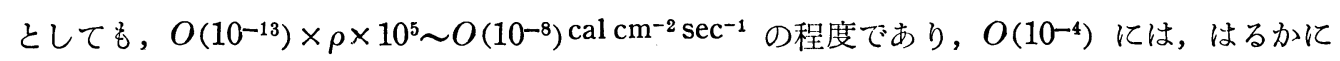
改ばない，余程異常な，故射性物質の集中が無い限り，作業物質内部の放射性エネルギーで， 松沢過程を維持することは，不可能である. 一方，熱が作業物質に外部から供給される場合と しては，熱伝導と熱対流の二つを考える.

b. 熱伝導 地表では，先にのべたように，平均 $1.3 \times 10^{-6} \cdot \mathrm{cal} \mathrm{sec}^{-1} \mathrm{~cm}^{-2}$ の熱の流れが観 测されている. 地殼の熱伝導率を $0.006 \mathrm{cal} \mathrm{sec}^{-1} \mathrm{~cm}^{-2} \mathrm{deg}^{-1}$ として温度勾配は, $20^{\circ} \mathrm{C} \mathrm{km}^{-1}$ で ある．地殼内部の放射性熱エネルギーのため，多少温度勾配は深さと共に減るかも知れないが， ての值なら $60 \mathrm{~km}$ の深さで大体, 普通の岩石の融解点に達するので, ての温度勾配が, 地殼の 底まで保たれていると考える.

熱伝導のみによつて松沢過程を維持するためには，もし熱伝導率が，地殼下まで变らないな らば, 100 倍の温度勾配によつて, 叉もし温度勾配不変ならば, 100 倍の熱伝導率をもつ物質 をとおして，熱が供給されなければならない。

Basalt と Granite について, 熱伝導率の温度変化が, Poole によつて調べられている.(4)

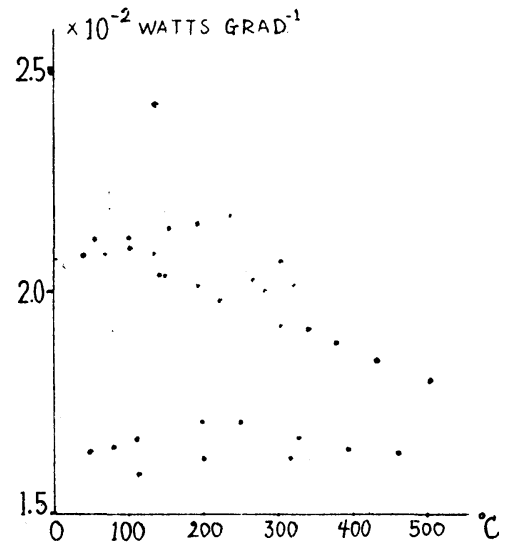

Fig. 2. Thermal conductivity of Basalt (after Poole)

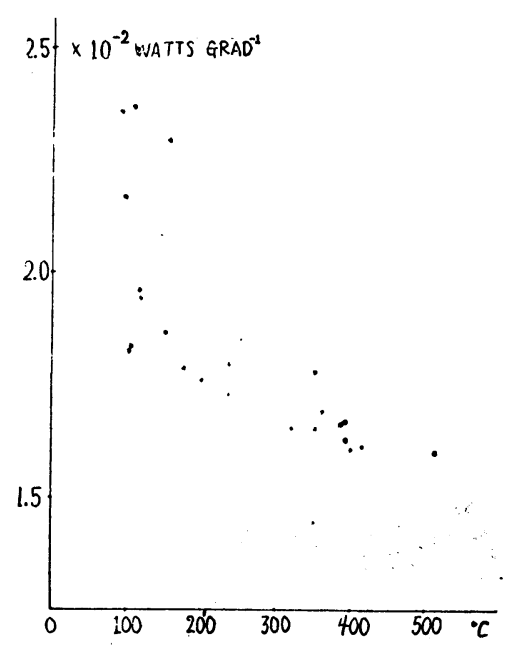

Fig. 3. Thermal conductivity of Granite (after Poole)

Fig. 2 に示されているように, Basalt では, 比較的低温の範囲で, 温度上昇に伴い熱伝導率 の増加心゙見られる. Granite では, Fig. 3 のように一様に減少し, 両者とも高温では, 温度 の上昇と其に減少する．温度の上昇と其に熱伝導率の増加する性質は, Graphite, Hematite, Quartz glass, Asbest, 等に見られるが，大部分の物質では，温度の上昇と基に減少する。熱 
伝導を分子振動による熱の輸送現象と考えると, 簡単な考えから ${ }^{(5)} K=\frac{4 k \nu}{a}$ という関係が 得られる. $a$ は分子間距離, $\nu$ は分子振動数である. それ故温度上昇に伴つて, 体積が増加す ると，Kは少さくなること，液化すれば更に小さくなることが予想される．しかし，圧力の

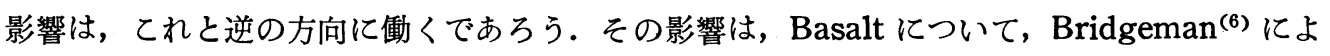
つて調べられている.それによれば，圧力が $0 〜 12,000$ bars の範用で次式が成立つ.

$$
\begin{aligned}
K & =0.00404+0.000019\left(\frac{P}{1000}\right)^{\left(\mathrm{cal}, \mathrm{sec}^{-1}, \mathrm{~cm}^{-2}, \mathrm{deg}^{-1}\right)} \text { at } 30^{\circ} \mathrm{C} \\
& =0.00414+0.0000089\left(\frac{P}{1000}\right) \quad \text { at } 75^{\circ} \mathrm{C}
\end{aligned}
$$

10,000 気圧 (深さ 35 籸程度) で, 2.1〜4.7\% 増加するに過ぎない. 300 籸の深さで 100,000 気圧に達するが, そこでもこの式が成立つとして, 高く 5 割の増加である. それ故, 松沢過程 を生ずる近傍では, 圧力, 温度によつて熱伝導率が著しく増加するてとはないと見てよいであ ろう.

物質が変って熱伝導率が大きくなるととがあるかも知れない. しかし，Fig. 4 亿示すよう

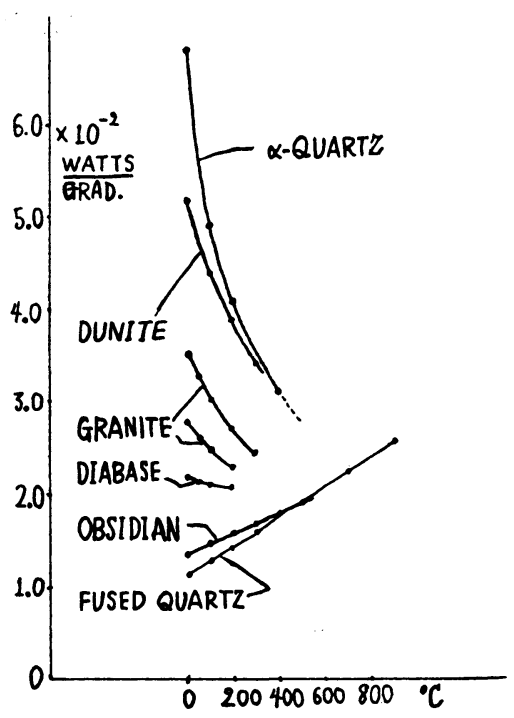

Fig. 4. Thermal conductivity of some rocks and minerals. (from Birch's table) に, Granite, Gabbro, Diabase, Dunite,など, 高 温になると皆余り異ならぬ值に近ずくように見える. 結局, 松沢過程の生ずる近傍では, 熱伝導率が地殼内 部と Order にわいて変らないと考えるのが妥当であ ろう.

とすれば，松沢過程のための熱の供給を熱伝導のみ で説明するには当然地殼内部の温度勾配 $20^{\circ} \mathrm{C} / \mathrm{km} の$ 100 倍の温度勾配が必要になる．たとえば，作業物質 が熱源から $5 \mathrm{~km}$ はなれているとしても，その間に $10,000^{\circ} \mathrm{C}$ の温度差が必要になる，そのような熱源を 想定するととは困難である.

c. 熱対流 熱対流による熱の伝達の問題は, 実験 的にも理論的にも古くから研究されている. その実験 は, Nusselt ${ }^{(7)(8)}$ による次元解析に基いており, 次の ような無次元数の間の関係を定めることを目的としている.

(1) Nusselt number $\quad N u=\frac{H l}{k \theta}$

$l$ は対流の規模をあらわす長さ， $k$ 熱伝導率， $\theta$ は流体と壁との温度差， $H$ は対流で運ばれ 
る熱の流れをあらわす. $N u$ は, 対流で運ばれる熱量と, 伝導で運ばれる熱量の比である.

(2) Reynolds number $\quad R e=\frac{U \rho l}{\mu}$

(3) Prandtl number $\operatorname{Pr}=\begin{gathered}c \mu \\ k\end{gathered}$

$c$ は比熱, $\mu$ は粘性係数である. これは, 粘性拡散 $\mu / \rho$ の熱拡散 $k / c \rho$ に対する比である.

(4) Grashof number $G_{r}=\frac{\alpha g \theta \rho^{2} l^{3}}{\mu^{2}}$

$\alpha$ は膨脹係数, てれは, 浮力に対する Reynolds number であつて, 例えば次のような運動 方程式， $\rho(V \cdot \operatorname{grad}) V=\rho g \alpha \theta$, を無次元化して生ずる係数 $\frac{g \alpha \theta}{U^{2} / l}$ に, 速度を消去するため に Reynolds number の自乗をかければ得られる.

地殸下に予想される熱詨流は, 何らかの力の場による強制対流ではなく, 熱膨脹による密度 変化で維持される自由対流であると考光る。の場合には一般流は考慮しないから, Reynolds number は除かれ, $N u$ が $G r$ と $\operatorname{Pr}$ によて定まる。更に, 理論的考案から, $N u$ は $\operatorname{Pr} \times G r$ の函数であると考光られている．てれには多少の批判があり，乱流になると成立たないと云わ れているが，層流に対しては，

$$
N u=C(P r \cdot G r)^{1 / 4}
$$

が理論的 ${ }^{(8)}$ に導かれる. 乱流の場合には

$$
N u=C^{\prime}(\operatorname{Pr} \cdot G r)^{1 / 3}
$$

実験は, 種々の幾何学的形態に対して, $\boldsymbol{C}, \boldsymbol{C}^{\prime}$ を求めている。次にその結果を表にして示す. 取扱われている物質は，air, water, oil, ethylene glicol 等である.

\begin{tabular}{|c|c|c|c|c|}
\hline 形 & $l$ & $c$ & $c^{\prime}$ & 観 测 \\
\hline 直 立 円 筒 & 高サ & 0.73 & 0.067 & Toulkian, Hawkins, Jacob \\
\hline 直 立 板 & 高サ & 0.64 & & Bosch, McAdams \\
\hline $\begin{array}{l}\text { 直立板あるいは大 } \\
\text { 半径の直立円筒 }\end{array}$ & 高サ & 0.56 & 0.12 & Saunder \\
\hline 水 平 板 & 巾 & 0.54 & 0.14 & Saunder \\
\hline 水 平 円 筒 & 直 径 & 0.53 & & Bosch, McAdams \\
\hline $\begin{array}{l}\text { 水平あるいは直立 } \\
\text { 円筒 }\end{array}$ & 直 径 & 0.47 & 0.10 & Saunder \\
\hline 二枚の水平板 & 間 隔/2 & 0.44 & 0.19 & Mull, Reiher \\
\hline 二枚の垂直板 & 間 隔/2 & $0.41 \times\left(\frac{L}{H}\right)^{1 / 9}$ & $0.18 \times\left(\frac{L}{H}\right)^{1 / 9}$ & Mull, Reiher \\
\hline
\end{tabular}

Table 2. The coefficients of equation (12) and (13) for several geometrical shapes. 
地殼下で，どのような形を通じて，熱の伝達が行われているかを解らないとしても，以上の

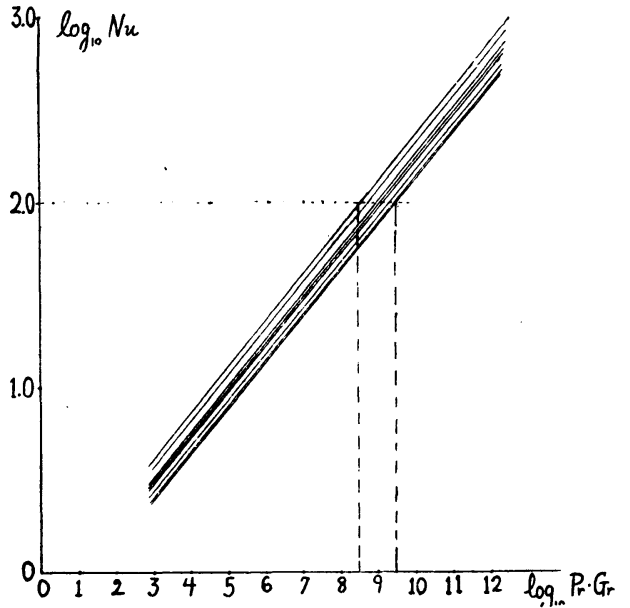

Fig. 5. Relation between the Nurselt and the

Rayleigh number for several geometrical shapes.
いくつかの形の内に含まれているとすれば，

$N u=100$ に対しては, Gr.Prは, Fig. 5 に示 すように, $10^{8.5} \sim 10^{9.5}$ の範囲内にある。との 罒は，層流に対する曲線である，Nu=100 と いうのは，地殼下で熱伝導率も温度勾配も地殼 内部と同程度であるとしたとき，松沢過程のた めに地殼内部の熱の流れの 100 倍の流れがある ことを意味する.

$\operatorname{Pr} G r$ が地殼下で $10^{8.5}$ 109.5 という值をと るととは,どういう意味をもつているであろう

これは, Benard 渦の発生を決定する Rayleigh number(9) 入 と全く同じものである. 此の 式に含まれている常数の中で, 比熱 $c$ と膨脹係数 $\alpha$ とは, 似た性質をもっていて, 両者とも絶 対零度で零であり, 温度と共に次第に増大し, 融点附近で異常に大きい値をとる. 又粘性係数 $\mu$ と熱伝導率 $k$ とは, 前者が運動量の, 後者が熱量の輸送現象に関係するという点で似てい る. そして, 似たもの同志が積の形で含まれているので, 状態の変化に敏感であるてとが予想 される.

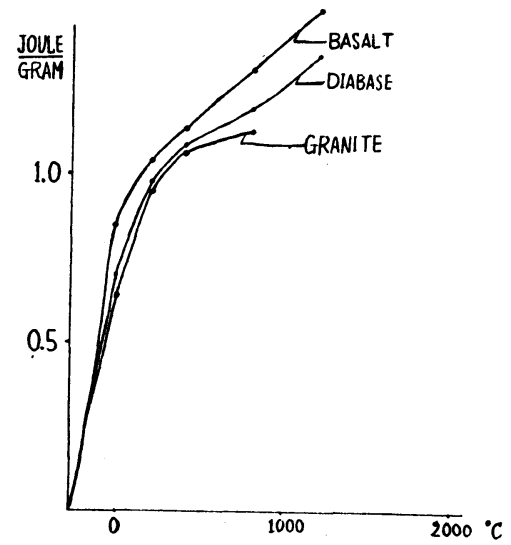

Fig. 6. Temperature dependence of heat capacity of some rocks. (from Birch's table)

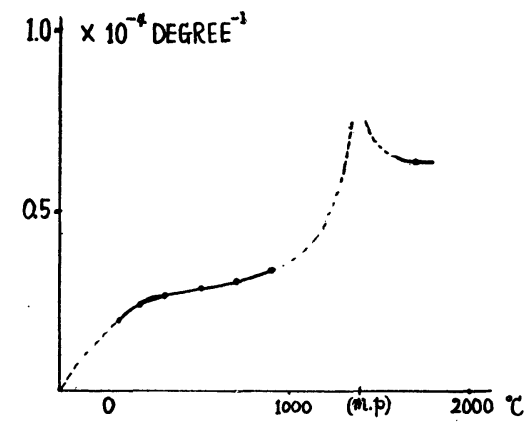

Fig. 7. Temperature dependence of thermal expansion of Disposide. (from Birch's table)

先ず比熱について調べた結果を Fig. 6 に示す. ${ }^{(3)}$ 比熱は Debye 温度以上では, 融点附近 
を除き, 殆んど変らない值をもつから, 余程気体に近い状態でない限り, 液体の範囲, 高温の固

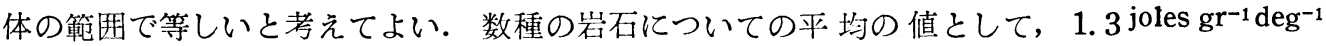
をとる.

熱膨脹係数については, Diopside のそれを Fig. 7 に示す。(3) 融点附近で異常なととは比 熱と同じであるが，液体としてとる值は，固体のときより大きくなる．岩石については，常温 における幾つかの標本の值の平均と，標本は異うが，液体のときの值とを次表に示す。一方熱

Table 3. Thermal expansion of rocks in solid and liquid state.

\begin{tabular}{l|l|c}
\hline Rock Type & $\alpha$ (at ordinary temp.) & $\alpha$ (liquid) \\
\hline Basalt & $1.5 \times 10^{-5} \mathrm{deg}^{-1}$ & $8.2 \times 10^{-5} \mathrm{deg}^{-1}$ \\
\hline Diorite & 2.1 & 14.0 \\
\hline
\end{tabular}

膨脹係数は，圧力の影響を大きくうける．アルカリ金属について Bridgeman の調べた所で は，一定の体積变化に対して，K, $N_{a}, L_{i}$ 共に同程度の割合で減少する．岩石の圧縮率は，

Table 4. Change of thermal expansion by the change of volume for Alkali metals (estimated from Bridgeman's data)

\begin{tabular}{c|c|c|c}
$-\Delta v / v_{0}$ & $\Delta \alpha / \alpha_{0}\left(L_{i}\right)$ & $\Delta \alpha / \alpha_{0}\left(N_{a}\right)$ & $\Delta \alpha / \alpha_{0}(K)$ \\
\hline 0.05 & 0.24 & 0.20 & 0.17 \\
\hline 0.10 & 0.42 & 0.37 & 0.35 \\
\hline
\end{tabular}

$1 \sim 2 \times 10^{-6} \mathrm{bar}^{-1}$ であつて, $10^{4}$ 気圧で $\frac{\Delta v}{v}=1 \sim 2 \times 10^{-2}, 10^{5}$ 気压で $\frac{\Delta v}{v}=1 \sim 2 \times 10^{-1}$, 程 度であるから, 相応状態の原理が成立つとして, 膨脹係数が, 300 籸位の深さで, 地表の值の 半分位になる可能性が充分ある. 以上のととを考虑して, 膨脹係数の值として, 融点附近を除 き $5 \times 10^{-5} \mathrm{deg}^{-1}$ を選んだ。

熱伝導率については，既にのべたが,その值として，

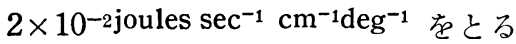

密度は, 2.6 とする.

温度勾配は，地殼内部と同一の值 $20^{\circ} \mathrm{C} / \mathrm{km}$ とする. 以上の諸量を用いて，Nusselt number が 100 であ る条件は, 次式で与えられる. $l$ を $\mathrm{km} て ゙ ， \mu$ を poise ではかり

$$
l^{4} \mu^{-1}=2.4 \times\left(10^{-8.5} \sim 10^{-9.5}\right)
$$

Fig. 8 に, $l^{4} \mu^{-1}=10^{-9}$ の曲線を示す. もし, 熱対 流が融点附近の状態で行われるなら，ての曲線は，

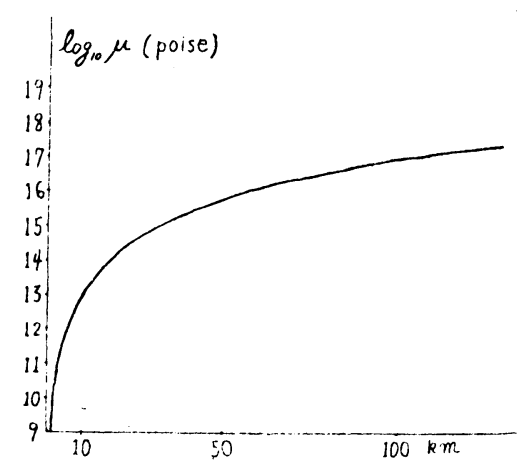

Fig. 8. Relation between the scale of convection current and the viscosity of material for the Nusselt number 100 . 
もつと上えあがり, $100 \mathrm{~km}$ の規模で粘性係数が $10^{20}$ poise 程度でよいという可能性もある.

実験の資料からは，速度を求めることが出来ないので，簡単な模型でそれを推定する.

§4. 速度の推定. Fig. 9 の如き座標系をとり, $y$ 軸に沿って, 下から高温の物質が上昇し,

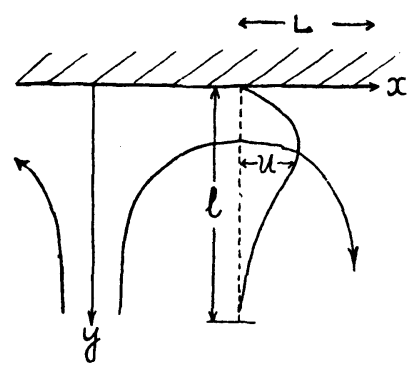

Fig. 9. Assumed velocity profile. $\boldsymbol{y}=0$ の壁で，両方に分れて流れるとする．熱の伝達の式は，

$$
\frac{D T}{D t}=a \nabla^{2} T, \quad a=\frac{k}{c \rho}
$$

定常であること, 及び

$$
\left|\begin{array}{cc}
u & \frac{\partial T}{\partial x}
\end{array}\right| \gg\left|v \frac{\partial T}{\partial y}\right|,\left|\frac{\partial^{2} T}{\partial y^{2}}\right| \gg\left|\frac{\partial^{2} T}{\partial x^{2}}\right|,
$$

を壁の近傍で仮定し，次式を得る.

$$
u \frac{\partial T}{\partial x}=a \frac{\partial^{2} T}{\partial y^{2}}
$$

$\boldsymbol{u}$ を壁の近傍で展開して，第一項のみをとり，

$$
u=\left(\frac{\partial u}{\partial y}\right)_{0} y=B y
$$

とおく（17) 式は,

$$
B y \frac{\partial T}{\partial x}=a \frac{\partial^{2} T}{\partial y^{2}}
$$

これを解くために， $w=y x^{-\frac{1}{8}}$ で変数変換すると，

$$
\frac{d^{2} T}{d \omega^{2}}+\frac{B}{3 a} \omega^{2} \frac{d T}{d \omega}=0
$$

てれを解いて，

$$
T=K_{1} \int_{0}^{\omega-\frac{B}{9 a} \omega^{3}} d \omega+K_{2}
$$

対流流体温度が上昇部で $t_{1}$ であり，壁の温度が $t_{0}$ であれば，境界条件は，

故に，

$$
\begin{array}{lll}
y=0, & w=0, & T=t_{0} \\
x=0, & w=\infty, & T=t_{1}
\end{array}
$$

$$
\begin{aligned}
& K_{2}=t_{0} \\
& K_{1}=t_{1}-t_{0} / \int_{0}^{\infty} e^{-\frac{B}{9 a} \omega^{3}} d \omega=\frac{3\left(\frac{1}{9}\right)^{\frac{1}{8}}}{\Gamma\left(\frac{1}{3}\right)}\left(t_{1}-t_{0}\right)\left(\begin{array}{c}
B \\
a
\end{array}\right)^{\frac{1}{8}}
\end{aligned}
$$

壁での温度勾配は，

$$
\left(\begin{array}{c}
\partial T \\
\partial y
\end{array}\right)_{0}=\frac{3\left(\frac{1}{9}\right)^{\frac{1}{8}}}{\Gamma\left(\frac{1}{3}\right)}\left(t_{1}-t_{0}\right)\left(\begin{array}{c}
B \\
a
\end{array}\right)^{\frac{1}{8}} x^{-\frac{1}{8}}
$$


熱の流れは, 長さ $L$ の壁について,

$$
\begin{aligned}
& Q=-\int_{0}^{L} k\left(\begin{array}{l}
\partial T \\
\partial y
\end{array}\right)_{0} d x=-\frac{3}{2} \cdot \frac{3\left(\begin{array}{c}
1 \\
9
\end{array}\right)^{\frac{1}{3}}}{\Gamma\left(\frac{1}{3}\right)} k\left(t_{1}-t_{0}\right)\left(\frac{B}{a}\right)^{\frac{1}{3}} L^{\frac{2}{3}} \\
& N u=-\frac{Q \cdot l}{L k\left(t_{1}-t_{0}\right)}=0.8 \times \frac{l}{L^{\frac{1}{3}}}\left(\frac{B}{a}\right)^{\frac{1}{3}}
\end{aligned}
$$

$B$ は，壁における速度勾配であり，乙れが，Nuによつてきまるととにはる.

$$
B=a \cdot \frac{L}{l^{3}}\left(\frac{N u}{0.8}\right)^{3}
$$

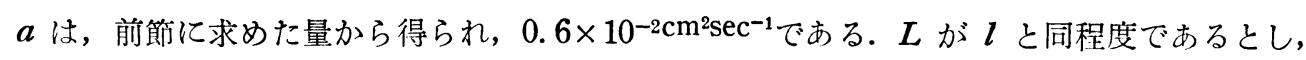
$N u=100$ に対して, $l$ を $\mathrm{cm}$ ではかれば.

$$
B=1.2 \times 10^{4} \times \frac{1}{l^{2}} \sec ^{-1}
$$

壁の受ける歪力は, $\mu B$ であるから，

$$
\tau=\mu B=O\left(10^{3}\right) \times l^{2} \text { dyne } \mathrm{cm}^{-2}
$$

但し $l$ は $\mathrm{km}$ ではかつてある.

一方, 速度分布を

$$
v=u_{1} \frac{y}{l}\left(1-\frac{y}{l}\right)^{2}
$$

と仮定する. これは，壁と $y=l$ とで， $x$ 方向の速度が零であるような流れをあらわす．てれ は只，壁における速度勾配と，最大速度の関係を適当に仮定するために採用したに過ぎないが，

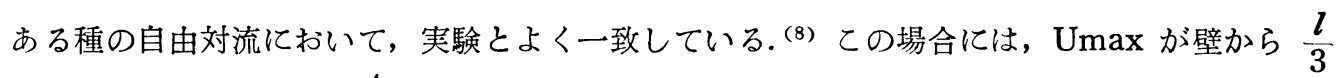
の所にあつて, $U \max =\frac{4}{27} B l$ である.

(26) 式に代入して,

$$
\mathrm{Umax}=0.17 \times 10^{4} \times i^{-1 \mathrm{~cm} \mathrm{sec}^{-1}}
$$

を得る. $l$ を $\mathrm{km}$ ではかり, Umax を $\mathrm{m}$ year $^{-1}$ ではかれば次のようになる.

$$
\mathrm{Umax}=5 \times 10^{3} \times l^{-1} \mathrm{~m} \text { year }^{-1}
$$

Fig. 10 及び Fig. 11 に対流規模によって異なる歪力の值と最大速度とを示した。

§5. 結 論 松沢過程は, 地殼下゙の熱の流れが，地殼内のそれの 100 倍程度ならば，必ず 起る.そして，そのような熱の流れは，熱対流によつてのみ可能である．たとえば， $10 \mathrm{~km} の$

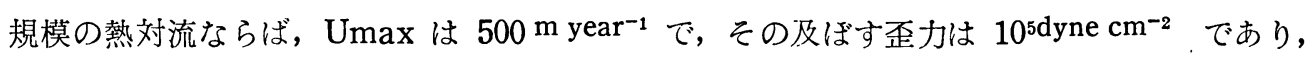
$100 \mathrm{~km}$ の規模の熱対流ならば，Umaxは 50 m year-1 $^{-1}$ でその及ばす歪力は $10^{7}$ dyne $\mathrm{cm}^{2}{ }^{2}$ であ 


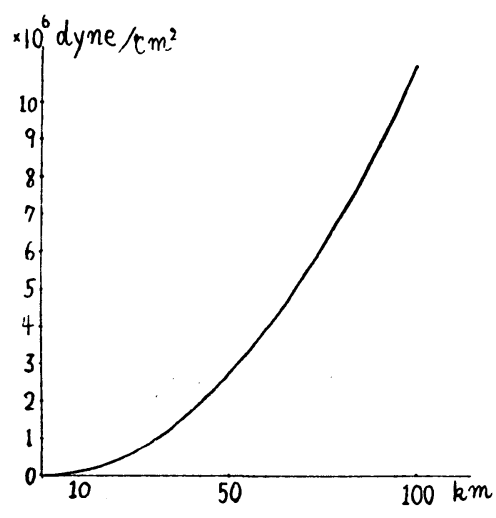

Fig. 10. Relation between the scale of convection current and the stress exerted in the case of Nusselt number 100.

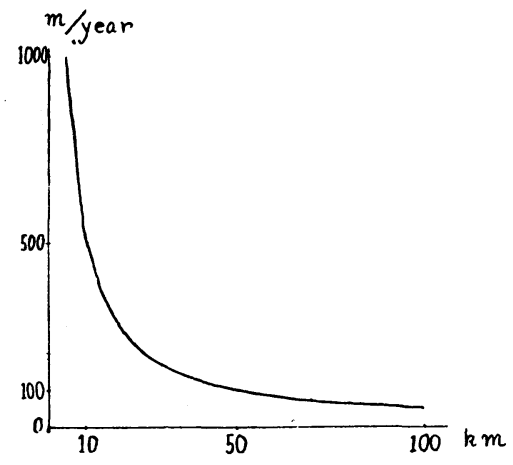

Fig. 11. Relation between the scale of convection current and its maximum velocity in the case of Nusselt number 100.

る. てのような熱対流があれば，松沢過程は必ず起る. それ故, 山脈形成を説明する subcrustal current が必然的に松沢過程を伴うこと, 大地震を説明する松沢過程が相当の歪力を伴う subcrustal current を必要とするてと, そして定常的な熱エネルギーの仕事えの転化がこの

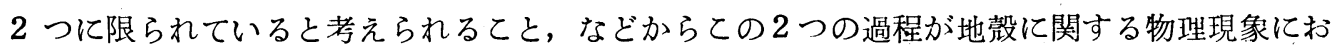
いて主要な役割を演じていると考えてよいであろう.

此の論文では，一成分系を考えにおいて議論したが，実際の地殼近傍では，多くの成分が， 融け合つているであろう.たとえば二成分が共融点にあつても, 定常的な熱の貯溜が可能であ り, 且つ共融点は, 融点より低いのが普通であるから, 対流が融点附近の状態で行われ松沢過 程は共融点附近の状態で行われるとともあり得るだろう. 対流の条件を決定する Rayleigh number は既に述べたように温度その他の状態によつて著しく変るから，それが地震の空間 的分布を規定する一つの重要な要素となつているとともあり得るだろう.

\section{参考文献}

(1) 坪井忠二: 「科学」 18 巻, 8 号, 9 号, (1948)

(2) T. Matuzawa: Feldtheorie der Erdbeben, B.E. R.I. 31 (1953) 179 202

(3) F. Birch: Hand book of Physical constants (1942).

(4) Constantes et Données numeriques.

（5） 戸田盛和：液体構造論, 共立出版, (1947) 134.

(6) P. W. Bridgeman: Physics of High Pressure.

(7) M. Fishenden and O. A. Saunders: An Introduction to Heat Transfer, Oxford (1950)

(8) E. Eckert: Wärme und Stoffaustausch, Springer Verlag, Berlin (1949).

(9) 竹内均, 高野健三: 科学, 23 巻 12 号 (1953) 